\title{
Nomenclature of drug-induced pityriasis rosea-like rashes
}

This article was published in the following Dove Press journal:

Neuropsychiatric Disease and Treatment

3 October 2015

Number of times this article has been viewed

\author{
Antonio AT Chuh \\ 'Prince of Wales Hospital, Hospital \\ Authority, ${ }^{2}$ The Jockey Club School \\ of Public Health and Primary Care, \\ Faculty of Medicine, Chinese \\ University of Hong Kong, Shatin, \\ Hong Kong
}

\section{Dear editor}

I read with admiration an article published in your prestigious journal on the rare adverse effects of clozapine (CLZ). ${ }^{1}$

I write to address a specific issue in this article. In the second paragraph of the section "Dermatological adverse effects", it was stated that a 54-year-old patient with schizophrenia treated for 28 days with CLZ developed a generalized rash compatible with pityriasis rosea (skin rash that usually begins as one large circular or oval spot on your chest, abdomen, or back).

I wish to point out certain problems for coining pityriasis rosea (PR) as the diagnostic label in the patient concerned.

First, PR is a paraviral exanthem that might be associated with primary infections or endogenous reactivations of human herpesvirus- $7,-6,2,3$ or other viruses. ${ }^{4,5}$ The underlying immunopathogenesis of PR is likely to be entirely different from that in PR-like drug eruptions. ${ }^{6}$

Second, rashes with morphological and distributional resemblances to PR that may be caused by drugs are currently considered as a separate condition distinct from PR in ICD-10. ${ }^{7}$ Thus, we recommend a revision to "pityriasis rosea-like drug eruption" as the diagnostic label in the article. ${ }^{1}$

Third, quoting the diagnostic label as "PR-like drug eruption" is compatible with the current diagnostic criteria ${ }^{8,9}$ and the modern classification ${ }^{10}$ of PR.

Fourth, it was stated that PR is "....skin rash that usually begins as one large circular or oval spot on your chest, abdomen, or back, ..." This statement refers to PR in general and is incorrect as only about $30 \%-40 \%$ of patients with PR have identifiable herald patches. ${ }^{6}$ Moreover, it gives us no information on the morphology, distribution, and time sequence of rash for the 54-year-old patient with schizophrenia.

The characteristics of PR-like drug eruptions are 1) absence of the herald patch, 2) bright violet-red color of the rash with marked inflammation, 3) being more pruritic, 4) dominance of eosinophils in the skin infiltrate, and 5) eosinophilia in the peripheral blood. ${ }^{11}$

From reading the article by De Fazio et $\mathrm{al}^{1}$ the readers could get a false impression that PR-like drug eruptions usually begin as one larger circular or oval spot. The reverse is true - there is usually no herald patch for PR-like drug eruptions. It is thus not an issue of nomenclature per se - it might lead to confusions to readers and other investigators as to the clinical manifestations of PR-like drug eruptions.

Fifth, most recent articles coin the term "PR-like drug eruptions" rather than "PR" for drug-induced PR-like rashes. ${ }^{12-15} \mathrm{I}$ advocate that this convention should be followed.
The Jockey Club School of Public Health and Primary Care, Faculty of Medicine, Chinese University of Hong Kong, Prince of Wales Hospital, 30-32 Ngan Shing Street, Shatin, NT, Hong Kong Email antonio.chuh@yahoo.com.hk 
Finally, some patients with PR-like drug eruptions could have been recruited into clinical studies and trials (Villarama and Lansang, unpublished data, 2003). ${ }^{16,17}$ I recommend that such practices be discontinued.

Therefore, I hope that through this item of correspondence, the status of PR-like drug eruption can be rectified.

Otherwise, I am extremely impressed by the high quality of the article by De Fazio et $\mathrm{al}^{1}$ and reading the article has been of immense educational value for me.

\section{Disclosure}

The author reports no conflicts of interest in this communication.

\section{References}

1. De Fazio P, Gaetano R, Caroleo M, et al. Rare and very rare adverse effects of clozapine. Neuropsychiatr Dis Treat. 2015;11:1995-2003.

2. Drago F, Ranieri E, Malaguti F, Losi E, Rebora A. Human herpesvirus 7 in pityriasis rosea. Lancet. 1997;349(9062):1367-1368.

3. Drago F, Ranieri E, Malaguti F, Battifoglio ML, Losi E, Rebora A. Human herpesvirus 7 in patients with pityriasis rosea. Electron microscopy investigations and polymerase chain reaction in mononuclear cells, plasma and skin. Dermatology. 1997;195(4):374-378.

4. Wong WR, Tsai CY, Shih SR, Chan HL. Association of pityriasis rosea with human herpesvirus-6 and human herpesvirus-7 in Taipei. J Formos Med Assoc. 2001;100(7):478-483.

5. Chuh AA, Chiu SS, Peiris JS. Human herpesvirus 6 and 7 DNA in peripheral blood leucocytes and plasma in patients with pityriasis rosea by polymerase chain reaction: a prospective case control study. Acta Derm Venereol. 2001;81(4):89-90.

6. Chuh A, Zawar V, Sciallis G, Law M. Gianotti-Crosti syndrome, pityriasis rosea, asymmetrical periflexural exanthem, unilateral mediothoracic exanthem, eruptive pseudoangiomatosis, and papular-purpuric gloves and socks syndrome - succinct reviews and arguments for a diagnostic criteria. Infect Dis Rep. 2012;4(1):38-48.
7. Centers for Disease Control and Prevention. International Classification of Disease, Tenth Revision. Atlanta, GA: Centers for Disease Control and Prevention. Available from: http://www.cdc.gov/nchs/icd/icd10. htm. Accessed August 22, 2015.

8. Chuh AAT. Diagnostic criteria for pityriasis rosea - a prospective case control study for assessment of validity. J Eur Acad Dermatol Venereol. 2003;17(1):101-103.

9. Zawar V, Chuh A. Applicability of proposed diagnostic criteria of pityriasis rosea - results of a prospective case-control study in India. Indian J Dermatol. 2013;58(6):439-442.

10. Zawar V, Chuh A. Follicular pityriasis rosea - case report and a new classification of clinical variants of the disease. J Dermatol Case Rep. 2012;6(2):36-39.

11. Atzori L, Pinna AL, Ferreli C, et al. Pityriasis rosea-like adverse reaction: review of the literature and experience of an Italian drugsurveillance center. Dermatol Online J. 2006;12(1):1.

12. Makdisi J, Amin B, Friedman A. Pityriasis rosea-like drug reaction to asenapine. J Drugs Dermatol. 2013;12(9):1050-1051.

13. Mokni S, Belhadjali H, Alkhalifa J. Pityriasis rosea-like adverse reaction induced by pristinamycine. Therapie. 2013;68(5):326-328.

14. Ohtsuka T. Pityriasis rosea-like arranged eruption after infliximab therapy in a patient with psoriasis vulgaris. J Dermatol. 2014;41(4): 354-355.

15. Panda M, Patro N, Jena M, Dash M, Mishra S. Pityriasis rosea like drug rash - a need to identify the disease in childhood. J Clin Diagn Res. 2014;8(8):YD01-YD02.

16. Lazaro-Medina A, Villena-Amurao C, Dy-Chua NS, et al. A clinicohistopathologic study of a randomized double-blind clinical trial using oral dexchlorpheniramine $4 \mathrm{mg}$, betamethasone $500 \mathrm{mcg}$ and betamethasone $250 \mathrm{mcg}$ with dexchlorpheniramine $2 \mathrm{mg}$ in the treatment of pityriasis rosea: a preliminary report. J Phil Dermatol Soc. 1996;5:3-7.

17. Zhu QY. The observation of curative effects of glycyrrhizin in treating pityriasis rosea. J Clin Dermatol. 1992;21(1):43. 


\section{Authors' reply \\ Pasquale De Fazio' \\ Raffaele Gaetano' \\ Mariarita Caroleo' \\ Gregorio Cerminara' \\ Francesca Maida ${ }^{2}$ \\ Antonio Bruno 3 \\ Maria Rosaria Muscatello ${ }^{3}$ \\ Maria Jose Jaén Moreno ${ }^{4}$ \\ Emilio Russo ${ }^{2}$ \\ Cristina Segura-García'}

'Department of Health Sciences, School of Specialization in Psychiatry, ${ }^{2}$ Department of Health Sciences, School of Specialization in Pharmacology, University "Magna Graecia,"

Catanzaro, Calabria, Italy; ${ }^{3}$ Department of Neurosciences, School of Specialization in Psychiatry, University of Messina, Messina, Italy; ${ }^{4}$ Department of Social Health Sciences, Radiology and Physical Medicine, University of Cordoba, Cordoba, Spain

Correspondence: Pasquale De Fazio

Department of Health Sciences, School of Specialization in Psychiatry, University “Magna Graecia,” Campus Universitario, Viale Europa, 88100

Catanzaro, Italy

Tel +390961712393

Fax +390961712393

Email defazio@unicz.it

\section{Dear editor}

We thank Dr Chuh for his comments and all suggestions addressed at improving the quality of our paper.

According to our review, the discussion about dermatological effects of clozapine treatment was focused on the rare causes of "pityriasis rosea (PR)-like eruption" defined as "a common cutaneous adverse reaction related to many drugs". ${ }^{1}$

Moreover, we considered it to be useful to underline that numerous recent studies in search for the etiology of pityriasis rosea (PR) did not pinpoint a definite viral, ${ }^{2-4}$ other infectious, ${ }^{5}$ or other causes. ${ }^{6}$

Therefore, these clinical patterns are not all or nothing and appear with variable magnitudes of atypical PR rash. ${ }^{7,8}$ The case report we have described in the review refers to "a generalized rash 'compatible' with pityriasis rosea", or rather a "PR with atypical forms", and even though the issue could be described in detail, it was useful to include in the discussion what the latest literature has reported on this topic.

\section{Disclosure}

The authors report no conflicts of interest in this communication.

\section{References}

1. Lai YW, Chou CY, Shen WW, Lu ML. Pityriasis rosea-like eruption associated with clozapine: a case report. Gen Hosp Psychiatry. 2012; 34:e5-e7.

2. Rebora AE, Drago F. A novel influenza a (H1N1) virus as a possible cause of pityriasis rose? J Eur Acad Dermatol Venereol. 2011;25:991-992.

3. Prantsidis A, Rigopoulos D, Papatheodorou G, et al. Detection of human herpesvirus 8 in the skin of patients with pityriasis rosea. Acta Derm Venereol. 2009;89:604-606.

4. Canpolat Kirac B, Adisen E, Bozdayi G, et al. The role of human herpesvirus 6, human herpesvirus 7, Epstein-Barr virus and cytomegalovirus in the aetiology of pityriasis rosea. J Eur Acad Dermatol Venereol. 2009; 23:16-21

5. Chuh AA, Chan HH. Prospective case-control study of chlamydia, legionella and mycoplasma infections in patients with pityriasis rosea. Eur J Dermatol. 2002;12:170-173.

6. Chuh AA. A prospective case control study of autoimmune markers in patients with pityriasis rosea. Clin Exp Dermatol. 2003;28:449-450.

7. Chuh A, Zawar V, Lee A. Atypical presentations of pityriasis rosea-case presentations. J Eur Acad Dermatol Venereol. 2005;19:120-126.

8. Zawar V. Oligo-lesional eruptions rapidly following a herald plaque: abortive pityriasis rosea. Indian J Dermatol. 2011;56:450-451.

Dove Medical Press encourages responsible, free and frank academic debate. The content of the Neuropsychiatric Disease and Treatment 'letters to the editor' section does not necessarily represent the views of Dove Medical Press, its officers, agents, employees, related entities or the Neuropsychiatric Disease and Treatment editors. While all reasonable steps have been taken to confirm the content of each letter, Dove Medical Press accepts no liability in respect of the content of any letter, nor is it responsible for the content and accuracy of any letter to the editor.

\section{Publish your work in this journal}

Neuropsychiatric Disease and Treatment is an international, peerreviewed journal of clinical therapeutics and pharmacology focusing on concise rapid reporting of clinical or pre-clinical studies on a range of neuropsychiatric and neurological disorders. This journal is indexed on PubMed Central, the 'PsycINFO' database and CAS, and is the official journal of The International Neuropsychiatric Association (INA). The manuscript management system is completely online and includes a very quick and fair peer-review system, which is all easy to use. Visit http://www.dovepress.com/testimonials.php to read real quotes from published authors. 